\title{
Why we should invest further in the development of internal combustion engines for road applications
}

\author{
Luka Lešnik $^{1, *}$, Breda Kegl ${ }^{1}$, Eloísa Torres-Jiménez ${ }^{2}$, and Fernando Cruz-Peragón ${ }^{2}$ \\ ${ }^{1}$ Faculty of Mechanical Engineering, University of Maribor, Smetanova ulica 17, SI-2000 Maribor, Slovenia \\ ${ }^{2}$ Department of Mechanical and Mining Engineering, University of Jaén, Campus las Lagunillas, s/n, 23071 Jaén, Spain
}

Received: 19 September 2019 / Accepted: 2 July 2020

\begin{abstract}
The majority of on-road vehicles today are powered by internal combustion engines, which are, in most cases, burning petroleum-derived liquid fuels mixed with bio-components. The power to weight ratio of internal combustion engines combined with the high energy content of conventional fuels, which can be refilled easily in matter of minutes, makes them ideal for all kinds of road transportation. Since the introduction of EURO emissions norms, the emissions from the Transport sector in the European Union have undergone significant reduction. There are several alternatives to fossil fuels with similar properties, which can replace their usage in the Transport sector. The main focus of research in recent decades has been on biofuels, which can be produced from several sources. The production of biofuels is usually energy more intensive than production of fossil fuels, but their usage can contribute to emission reduction in the Transport sector. In recent years, a lot of effort was also put into promotion of electric vehicles as zero emissions vehicles. This statement should be reconsidered, since the greenhouse impact of electrical vehicles is not negligible. Conversely, in some cases, an electrical vehicle can have an even higher emission impact than modern vehicles with sophisticated internal combustion engines. This is characteristic for countries where the majority of the electricity is produced in coal power plants. With the decrease of greenhouse gas emissions in the Electricity Production sector, and with the increase of battery capacity, the role of electric vehicles in the Transport sector will probably increase. Despite significant research and financial investments in electric vehicles development, the transport sector in near future will be mostly powered by internal combustion engines and petroleum-derived liquid fuels. The amount of pollution from transport sector will be further regulated with stricter emission norms combined with smaller amount of alternative fuel usage.
\end{abstract}

\section{Introduction}

The global energy demand is increasing almost every year. In the year 2017, the total World primary energy consumption increased by $2.1 \%$, which increases the need for new energy sources [1,2]. Most of today's global energy demands are obtained by the burning of fossil fuels. Oil still remains the dominant fuel, with $34 \%$ global market share. It is followed by coal and gas, which have $27.6 \%$ and $23.4 \%$ global market shares respectively. The global market share of renewable energy is increasing constantly and reached a $13.6 \%$ share in the year 2017. The structure of primary energy consumption in the European Union $(E U)$ is very similar to global, Figure 1.

In 2016, fossil fuels accounted for more than $72 \%$ of total primary energy consumption in the $E U$. Solid fuels (coal,

\footnotetext{
* Corresponding author: luka.lesnik@um.si
}

coke, peat, oil shale and oil sand) accounted for $14.8 \%$, crude oil and petroleum products $34.9 \%$, and gas for $23.6 \%$ respectively. Nuclear energy and Renewable Energies (RE) accounted for $13.3 \%$ each. All solid and liquid biofuels, biogas, hydro power, wind power, solar energy, geothermal energy and renewable waste are included in the Renewable Energies category.

Figure 2 presents the trend of global and European Union primary energy consumption and production of carbon dioxide $\left(\mathrm{CO}_{2}\right)$.

A clear connection between primary energy consumption and carbon dioxide emissions for the World and $E U$ are evident from the results presented in Figure 2. Total World energy consumption is increasing rapidly compared to the energy consumption in the European Union, which is fluctuation on more or less the same level since 1990. The main reason for the increase in World primary energy consumption is the rapid development of China, India and other Asian non $O E C D$ countries [3]. The increase of 


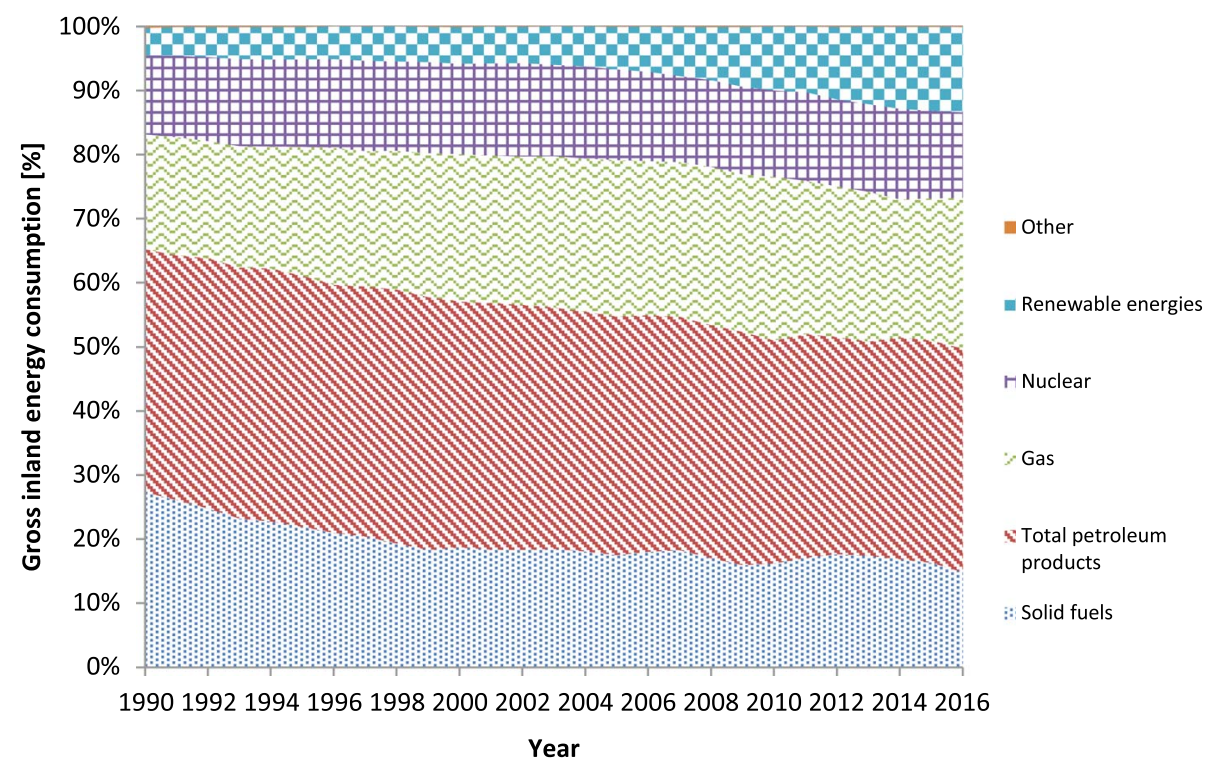

Fig. 1. Primary energy consumption in the $E U[51,52]$.

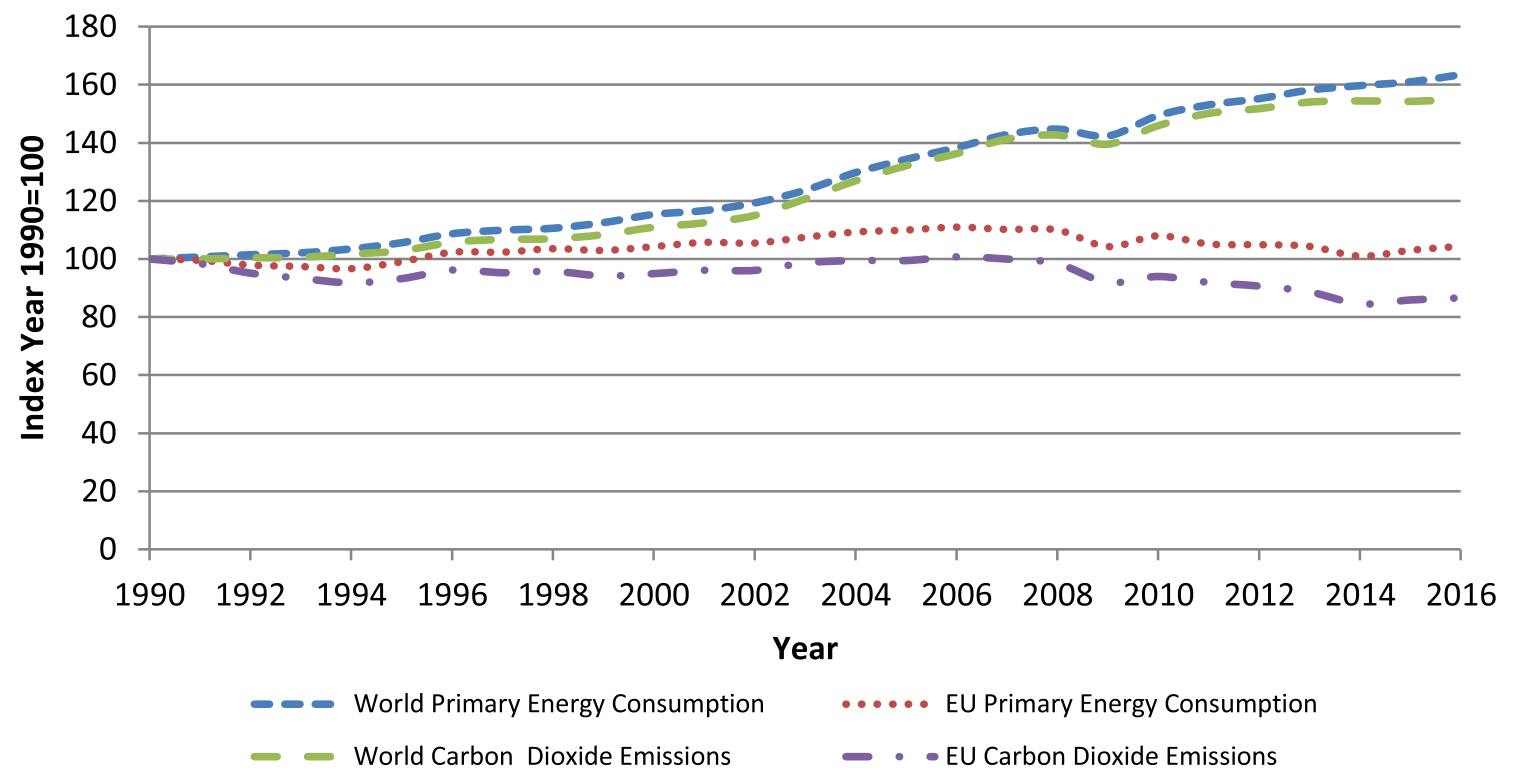

Fig. 2. Global and $E U$ trends of energy consumption and $\mathrm{CO}_{2}$ emissions $[1,2]$.

Renewable Energy market share contributed to the stabilization of $\mathrm{CO}_{2}$ emissions' growth in recent years.

The increase in primary energy demands and decrease in fossil fuel consumption in the $E U$ were covered by the increase in market share of Renewable Energies and gas. During the period from 1990 to 2016, the market share of Renewable Energies increased from $4.3 \%$ to $13.3 \%$, Figure 1.

The presented paper studies the current situation in the European Union Passengers Transport sector energy consumption, emission formation and propulsion systems technology. The applicability of different alternative propulsion systems to conventional diesel and gasoline engines was also studied in the presented paper. The paper also considered some of the new engine technologies and their potential for fuel consumption and emission formation reduction. At the end, the energy and emission intensity of different propulsion systems and different fuels were compared with the conventional direct injection spark ignition and direct injection compression ignition engines.

\section{Transport sector in the $E U$}

The energy produced from primary sources is used in several sectors of human activities. The European Union 


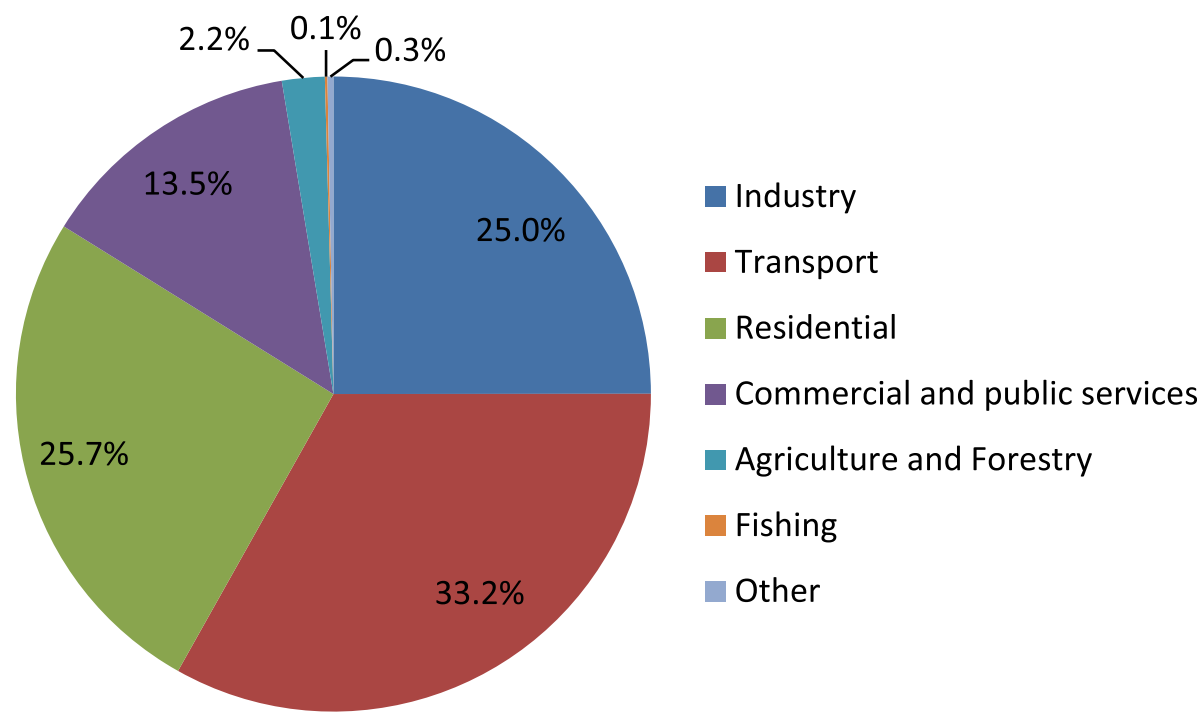

Fig. 3. EU primary energy consumption by sectors [3].

primary energy consumption can be divided further on consumption in specific sectors, Figure 3.

The ratio of energy consumption in specific sectors indicates that the Transport sector in the $E U$ contributes to one-third of the total primary energy consumption. The second biggest energy consumption sector is the residential sector with $26 \%$, followed by the Industry sector, which consumes one quarter of the primary energy.

In statistics, the Transport sector is further divided into rail, road, international aviation, domestic aviation, domestic shipping and other transport sectors. Figure 4 presents the structure of the final European energy consumption in the Transport sector.

The results presented in Figure 4 indicate that most of the energy in the Transport sector is consumed by road transport. According to [4] passenger transport accounts for approximately $61 \%$ of the total energy consumption in the EU Transport sector.

The total structure of energy consumption by fuel type in Million Tera Joules (MTJ) and the structure of the passenger and freight transport sector in the $E U$ are presented in Table 1.

It can be seen from the data presented in Table 1 that fossil fuel presents the majority of the fuels used in the Transport sector. Diesel fuel still remains the most sold fuel for road transport, with $67 \%$ market share in 2016. In the total Transport sector, diesel fuel accounts for approximately $49.4 \%$ market share $[5,6]$. The share of Renewable Energy usage in the EU Road Transport sector was only $7.1 \%$ in 2016 [5]. Most of the Renewable Energy in the Passenger Transport sector is obtained by mixing biofuels with conventional fuels in small ratios [7].

The structure of fuels used in the Transport sector is a reflection of the new vehicle registration market share. In 2016, diesel passenger cars represented a $49 \%$ market share of new passenger cars registered in the European Union [8].

Considering the structure of the Transport sector and fuels used, there is no doubt that combustion of fossil fuels

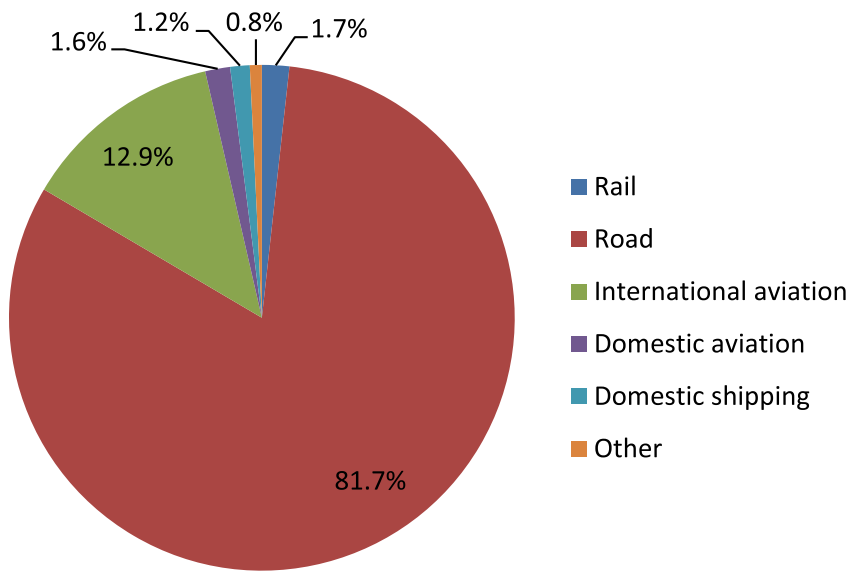

Fig. 4. Final energy consumption in the EUTransport sector [3].

in internal combustion engines for road applications produces significant amounts of $\mathrm{CO}_{2}$ and other exhaust gas emissions. The trends in transport emissions of Carbon Oxide (CO), Non-Methane Volatile Organic Compounds (NMVOC), Sulphur Oxides $\left(\mathrm{SO}_{\mathrm{x}}\right)$, Nitrogen Oxides $\left(\mathrm{NO}_{\mathrm{x}}\right)$ and Particulate Matter PM2.5, are presented in Figure 5.

The results presented in Figure 5 show that all presented transport emissions in the $E U$ have undergone major reduction between the years 1990 and 2016. The Carbon Oxide and Non-Methane Volatile Organic Compounds' emissions underwent the biggest reduction, which was approximately $85 \%$. Sulphur Oxides and Nitrogen oxides underwent $64 \%$ and $41 \%$ reductions respectively. The obtained reduction of PM2.5 emissions from the years 2000 to 2016 was around $42 \%$.

Road transport exhaust gas emissions in the European Union account for $18.9 \%$ of total EU Carbon Oxide emissions, $6.3 \%$ of total EU NMVOCs emissions, $28.6 \%$ of total EU $\mathrm{NO}_{\mathrm{x}}$ emissions, $3.1 \%$ of total Particulate Matter PM10 
Table 1. Structure by fuel type and structure of passenger and freight $E U$ transport sector $[4,5,12,51,53]$.

\begin{tabular}{lcccc}
\hline Fuel type in transport sector & $\%$ & MTJ & Land and water transport & $\%$ \\
\hline Road diesel & 49.4 & 8.4 & Passenger transport & 61 \\
Road gasoline & 18.8 & 3.2 & Passenger cars & 83.1 \\
Aviation kerosene & 12.9 & 2.2 & Motor coaches. buses and trolley buses & 9.2 \\
Ship residual fuel oil & 8.2 & 1.4 & Trains & 7.7 \\
Ship diesel/gas oil & 3.5 & 0.6 & Freight transport & 39 \\
Biodiesel & 2.9 & 0.5 & Roads & 76.4 \\
Rail electricity & 1.2 & 0.2 & Railways & 17.4 \\
Liquefied petroleum gas & 1.2 & 0.2 & Inland waterways & 6.2 \\
Rail gas/diesel oil & 0.6 & 0.1 & & \\
Bio gasoline & 0.6 & 0.1 & & \\
Natural gas & 0.6 & 0.1 & & \\
\hline
\end{tabular}

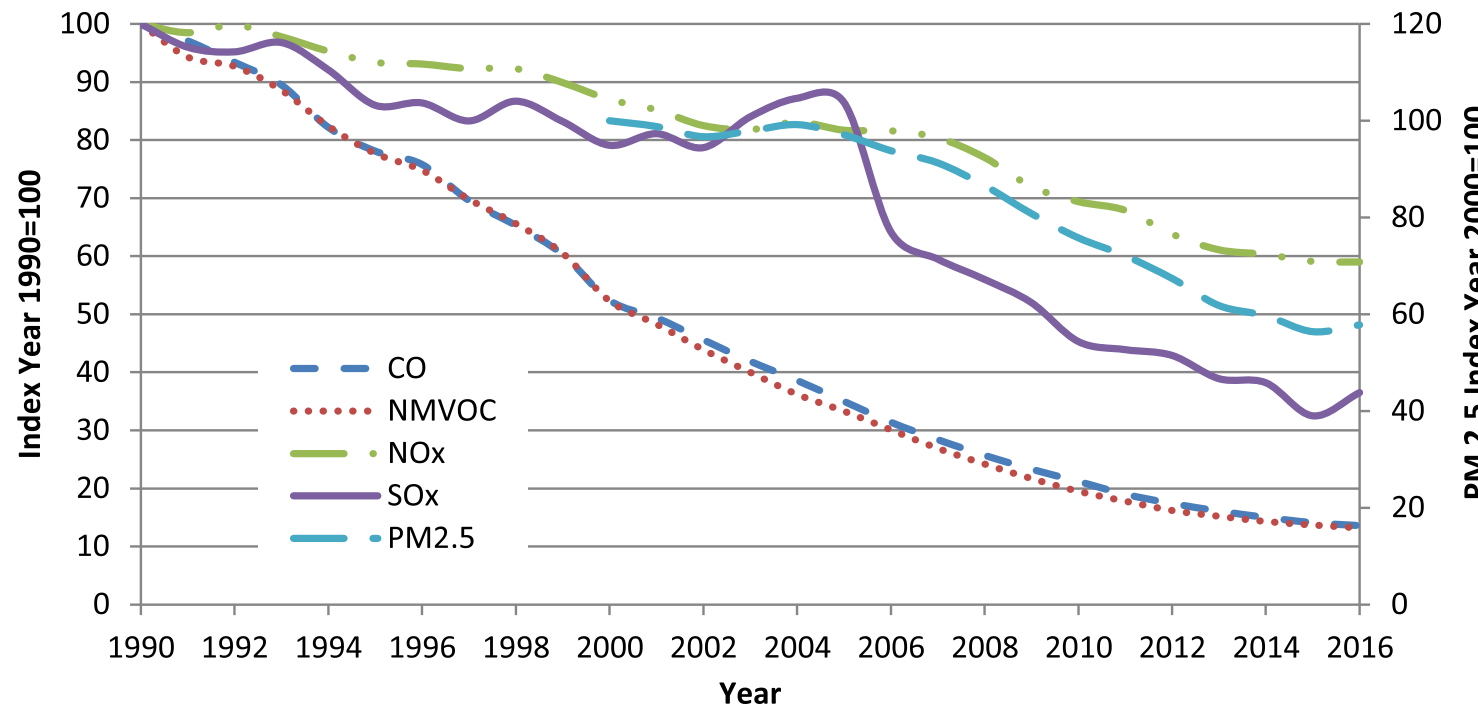

Fig. 5. Trend in emissions of air pollutants from the Transport sector in the $E U[9,54]$.

EU emissions, 5.8\% of total EU Particulate Matter PM2.5, and $1 \%$ of total EU $\mathrm{SO}_{\mathrm{x}}$ emissions. There is also a significant contribution of $E U$ road transport non-exhaust emissions. It contributes $2 \%$ of total EU NMVOCs, $4.6 \%$ of total PM10 EU emissions and $4.2 \%$ of total PM2.5 EU emissions [9].

The reduction of transport emissions is a result of several factors. In road transport, the implementation of EURO emission standards, which define acceptable limits for exhaust gas emissions of new vehicles sold in the $E U$, are the main contributor to emissions' reduction in the $E U$. Their implementation contributed to the introduction of Gasoline Direct Injection (GDI) systems, Engine Control Units (ECU) and catalytic converters in vehicles with gasoline engines. In vehicles with diesel engines, the EURO norms led to the implementation of common rail systems, Exhaust Gas Recirculation (EGR) systems and diesel particulate filters. More recent EURO norms led to the development and introduction of Selective Catalytic Reduction (SCR) systems, Diesel Oxidations Catalyst (DOC) and lean
$\mathrm{NO}_{\mathrm{x}}$ traps in modern diesel vehicles. The turbocharger systems and downsized engine volumes were introduced in both diesel and gasoline engines. All those systems helped to decrease $\mathrm{CO}, \mathrm{NO}_{\mathrm{x}}, \mathrm{HC}$ and $\mathrm{PM}$ exhaust gas emissions [10]. The emission reduction was also influenced by changes in fuel quality. Higher octane number gasoline fuels and higher cetane number diesel fuels allowed engine manufacturers to produce engines with higher compression ratios, and to obtain higher engine efficiency and lower specific fuel consumption. The introduction of $E U$ Directives relating to the sulphur content in liquid fuels also contributed to a reduction in Sulphur Oxides' $\left(\mathrm{SO}_{\mathrm{x}}\right)$ emissions [11].

The improvements governed by the introduction of EURO norms led to improvement in internal combustion engines and other vehicle systems. Those improvements further influenced vehicle fuel consumption and $\mathrm{CO}_{2}$ emission production. The average vehicle fuel consumption and $\mathrm{CO}_{2}$ emissions of European cars tested on the NEDC cycle decreased by $27.9 \%$ and $30.2 \%$ respectively in 2016 compared to 2001. In the same period, the average engine rated 
power and weight of a European passenger car increased by $28.4 \%$ and $11.1 \%$ respectively. Despite all improvements and decrease in energy consumption, the road transport in the $E U$ still consumed $32 \%$ more energy in 2016 than it did in 1990 [12]. The main reason for the increase in road transport energy consumption is in the growth of the Road Transport sector. Since 1990, the average number of passenger cars per 1000 inhabitants in European Union countries increased by 1.7 times [13].

\section{Improvements of internal combustion engines and alternatives to petroleum based fuels}

In their evolution, vehicles and internal combustion engines went through numerous modifications, which were implemented in order to increase their performance, lower fuel consumption and decrease the formation of harmful exhaust gas emissions. Despite the fact that a lot of researchers nowadays focus on the development of alternative proportion systems, there is still some researches on how to improve conventional ICE efficiency, lower the exhaust gas emissions' production and optimise vehicle systems.

There are several options where we can employ modern technologies. Alternative fuels, like biodiesel, give us the option to influence emission reduction before fuel is combusted. Modern, new engine technologies, influence lower fuel consumption, a better combustion process and higher engine efficiency.

\subsection{Modern internal combustion engine technologies}

The first internal combustion engines had efficiency of a few percent, which has now increased to almost $50 \%$ for heavy duty, low speed marine diesel engines. Current systems in internal combustion engines, like valve opening systems, lubrication systems, cooling systems, injection systems, etc., can be further optimised. It is expected that the sum of all possible improvements in engine systems, combined with additional friction reduction, compression ratio increase, variable valve control on all operating regimes, two stage turbochargers, start/stop systems' introduction, and more efficient transmission systems combined with vehicle weight, tyre resistance and drag reduction, can reduce passenger vehicle fuel consumption by $20 \%$ in the next 10-15 years [14]. Slightly lower fuel consumption reduction can be expected in the European Union, since a lot of new cars already have downsized engines which are turbocharged. The higher fuel consumption reduction can be further achieved by introducing modern engine technologies not currently available on the market.

The main drawback of gasoline engines in achieving higher efficiency is their low compression ratio, compared to compression ignition engines. In traditional Spark Ignition (SI) gasoline engines, Compression Ratio (CR) is limited to a ratio of around 13 in order to avoid fuel knock and engine damage. A lot of work has been done in recent decades on gasoline injection systems and fuel dosing, where we experience the transition from carburettors to multi-port injection systems and to Gasoline Direct Injection (GDI).

In recent years, advanced gasoline engine concepts, like Gasoline Compression Ignition (GCI), Homogeneous Charge Compression Ignition (HCCI), Partially Premixed Combustion (PPC), Low Temperature Combustion (LTC), Octane On Demand (OOD), etc. were developed. Those concepts allow gasoline engines to operate at higher compression ratios up to 18, and achieve higher engine efficiency without increasing in-cylinder emission formation. Most of these concepts combine high pressure Gasoline Direct Injection, multiple injections per cycle, low and high Exhaust Gas Recirculation, variable valve timing, etc. in order to use gasoline in compression ignition engines with high compression ratio $[15,16]$. Some versions of these concepts, like Spark Controlled Compression Ignition (SPCCI), are commercially available from year 2019 .

Even higher engine efficiency and higher emission formation reduction are possible if new fuels and new engine concepts are developed simultaneously. The fuels with lower octane number $(\sim 70)$ can help to run compression ignition engines successfully in GCI mode [17, 18]. Such fuels can be produced in refineries from naphtha, which is processed further to make gasoline with sufficient octane number and other properties. The process of their production is less demanding and cheaper since low octane fuel requires less additives and less processing.

The operating concept of a Compression Ignition (CI) diesel engine with direct fuel injection allows them to operate at higher compression ratios and achieve higher efficiency compared to gasoline engines. The construction of modern diesel engines is very complicated and expensive. In order to control higher values of Particulate Matter, diesel engines must operate with a lean fuel mixture, which increases Nitrogen Oxides' production, so additional systems are required in order to control $\mathrm{NO}_{\mathrm{x}}$ production. A lot of work has been done on diesel engine injection systems in the recent decades. Higher injection pressure in CI engines usually leads to better spray atomization, enhances the mixing process of fuel and air, and is a very effective approach to increasing engine performance. The higher injection pressure also influences a more uniform atomization of fuel. High injection pressure enhances cavitation formation inside the injection nozzle, which influences a better spray break up process and higher fuel velocity at the nozzle exit [19-21]. Fuel spray formation and break up processes are also influenced by the number of injection holes and shape of the nozzle sac volume [22].

The fuel atomization, fuel air mixing process, increase in break thermal efficiency and emission reduction can be optimised further by the shape of the combustion chamber. Toroidal shape of the combustion chamber is proven to have a positive impact on engine operating parameters and lower emission production [23, 24].

\subsection{Exhaust gas after-treatment systems}

Using modern ICE technologies, exhaust gas emissions can only be reduced to a certain extent. So, additional exhaust gas after-treatment systems must be used in order to achieve emission regulations and to reduce air pollution. 
With the usage of these systems, exhaust gas emissions for modern EURO VI diesel and gasoline cars are more or less the same [25].

The main emissions to control/mitigate in gasoline SI engines are hydro carbons, Carbon Monoxide and Nitrogen Oxides' emission. Because gasoline engines operate at near Stoichiometric conditions, these emissions can be reduced efficiently using a three-way catalytic converter. These systems cannot operate sufficiently with excess oxygen in the exhaust gas, so they cannot be employed for usage in compression ignition diesel engines which are operating with a lean air fuel mixture [26].

The majority of modern diesel engines are using Exhaust Gas Recirculation (EGR) systems for reduction of $\mathrm{NO}_{\mathrm{x}}$ emissions. The $\mathrm{NO}_{\mathrm{x}}$ emission cannot be controlled completely with only EGR systems. In order to reduce $\mathrm{NO}_{\mathrm{x}}$ emission further, the majority of modern vehicles equipped with a diesel engine, have built in Selective Catalytic Reduction (SCR) systems. These systems are capable of further $\mathrm{NO}_{\mathrm{x}}$ emission reduction, using chemical reactions with reactants like ammonia or urea. Diesel engines also have a big problem with Particulate Matter, which can be reduced effectively by diesel particulate filters. A diesel oxidation catalyst can be employed in order to oxidise Carbon Oxide and hydrocarbons emission [27].

Exhaust gas after-treatment systems are an efficient way to reduce exhaust gas emissions, which are currently in use in all new vehicles sold in the $E U$. In future, more exhaust gas after treatment systems will be needed to achieve EURO norms. In an SI engine, gasoline particulate filters are expected to be used for Particulate Matter reduction, while in a CI engine, Lean $\mathrm{NO}_{\mathrm{x}}$ Traps (LNT) will help to reduce Nitrogen Oxides' emissions further.

\subsection{Alternative fuels}

Fossil fuels combustion emission can also be reduced by usage of alternative fuels. They are several alternatives to petroleum based fuels, currently available as fuels for Internal Combustion Engines. All these alternatives together account for around $5 \%$ of total energy demand in the Transport sector. In future it is expected that they can account for up to a $10 \%$ share of transport energy by the year 2040 [4, 28].

\subsubsection{Hydrogen}

Hydrogen is a very clean fuel which produces zero emissions at the vehicle tail pipe, and can be used to power passenger cars or commercial vehicles. The most common use of Hydrogen in transportation is to produce electricity in fuel cells which power the on-board electrical motor of Fuel Cell Electric Vehicles (FCEVs).

Pure Hydrogen cannot be found in the Earth's atmosphere in large quantities, so it must be produced in order to be used as a fuel. The production of Hydrogen requires a lot of energy, which determines the final Hydrogen vehicle emission footprint. The most common sources for Hydrogen production are coal, natural gas and water [4, 29].

The energy content of Hydrogen per volume unit at normal pressure and temperature is approximately
3100 times lower than gasoline at the same conditions. In order to use Hydrogen as fuel in vehicles, it needs to be compressed up to 700 bar, or liquefied by cooling it down to $-253{ }^{\circ} \mathrm{C}$. Both processes are very energy consuming, and pose a rather large problem for use in vehicles $[4,29,30]$.

The main problem with massive use of Hydrogen in the Transport sector is in its production, storage and distribution, which are all very expensive. This fact will probably limit its usage for special applications.

\subsubsection{Biofuels}

The reduction of $\mathrm{CO}_{2}$ emissions in the Transport sector is one of the key factors in achieving the desired total $\mathrm{CO}_{2}$ emission reduction. Biofuels are known as the key alternative to conventional fuels for reduction of $\mathrm{CO}_{2}$ emissions in the Transport sector [31, 32]. Currently, all diesel fuel sold in the European Union contains a few percent of biodiesel, while around $75 \%$ of gasoline contains $5 \%$ of ethanol [7].

Biofuels can be classified into four generations, which differ based on the type of feedstock used for their production. More than $90 \%$ of all currently used biofuels worldwide are first generation biofuels made from edible biomass. The second generation biofuels are made from lignocellulosic material derived from lignin, cellulose or hemicellulose. These biofuels are far more sustainable for usage compared to first generation biofuels, since the raw material for their production does not compete with possible sources of human food. Macro and micro algae present the third generation of biofuels. Algae are considered as materials with the highest oil content among various plants. Currently, algae biofuels' production is too expensive, so this type (generation) of biofuels is not competitive with the first and second generation biofuels. The main drawback in massive algae biofuels' production is in cost efficient supplies of $\mathrm{CO}_{2}$, nutrients and water source. The fourth generation of biofuels is still in the early stage of development. They are obtained from genetically modified microorganisms, like microalgae, fungi, cyanobacterial, or yeast [31, 33, 34].

\subsubsection{Synthetic fuels, Methanol and Dimethyl ether}

Liquid fuels can also be produced from sources containing a mixture of Hydrogen and Carbon Monoxide, which can be found in various forms, like natural gas, coal or biomass. The most appropriate and clean source for synthetic fuel production is Natural Gas (NG). The fuel made from NG is named GTL (Gas-To-Liquid). A lot of GTL fuel can be produced in petrol refineries, where Natural Gas is a byproduct which is usually burned in a gas flare, or it is released into the atmosphere, which harms the environment. Synthetic fuels made from coal are usually named CTL (Coal-To-Liquid), while BTL is an acronym for synthetic fuels from biomass (Biomass-To-Liquid).

The Fischer-Tropsch (F-T) process can be used to produce GTL from Natural Gas at petrol refineries, and also from other sources, which can contribute to decrease of environmental pollution, improve the energy efficiency of refineries, and produce high quality fuel for IC engines. Different catalysts and other processes used in the F-T process can produce both diesel or gasoline fuels [35]. 
Natural Gas, coal and biomass can also be used for production of Methanol and Dimethyl Ether (DME). Methanol has a high octane number, and is used mostly as a gasoline blending component. The main disadvantage of Methanol is its high toxicity and aggressiveness to fuel systems and their components. DME has a very high cetane number, so it is mostly used as a replacement fuel in diesel engines. The problem with extensive use of both Methanol and DME is in the infrastructure needed for their distribution [4].

\section{Use of electricity in transportation}

Electric Vehicles (EV) have been around for decades. They first appeared in the 19th century, when massive usage of vehicles with Internal Combustion Engines was not so popular because of the large difference in liquid fuels' properties and low quality of ICE's production. During and after the first and second world wars, the vehicles with ICE have become more reliable, which, combined with other factors, increased their popularity [36]. Since then, several versions of vehicles have been developed with an electric propulsion system. Based on the source of energy, they can be categorised as Hybrid Electric Vehicles (HEVs), Plug-in Hybrid Electric Vehicles (PHEVs), Fuel Cell Electric Vehicles (FCEVs) and Battery Electric Vehicles (BEVs).

\subsection{Battery Electrical Vehicles}

The BEVs use electricity as the only source of energy. The electrical energy (or electricity) is a vector of energy, and does not exist as a source in nature. It has to be generated and stored in order to be used as an energy source in BEVs and other types of EVs. The battery capacity has significant influence on everyday usability of an EV. The current battery energy density increased from $10-25 \mathrm{Wh} / \mathrm{kg}$ in the 19 th century to $80-150 \mathrm{Wh} / \mathrm{kg}$ in modern vehicles [37]. This increase in batteries' energy density and storage capacity was achieved by usage of lithium and other rare earth metals. Their usage influences the final price of a battery package, and makes a significant contribution to the life cycle emissions' production of battery electrical and hybrid vehicles. The production of lithium batteries accounted for $20 \%$ of BEV life-cycle emissions in Germany, which is a very carbon intense country from electricity production point of view, and for $50 \%$ in a carbonless intensive country like Norway which produce most of electricity using renewable sources [38].

The study of the International Council on Clean Transportation [38], showed that in a life-cycle over $150000 \mathrm{~km}$, an average $\mathrm{BEV}$ produces $50 \%$ less $\mathrm{CO}_{2}$ emissions than an average European car. This value is highly dependent on the type of energy production, and can vary between $28 \%$ and $72 \%$. If we compare $\mathrm{CO}_{2}$ emission production with the most efficient diesel car produced in 2016, the difference between an electric and conventional car decreases, or gets even in favour of diesel powered cars in some countries [13]. The average lifetime for a BEV is more than 20 years, and for battery pack between 5 and 15 years. This means that the total amount of $\mathrm{CO}_{2}$ emissions in a $\mathrm{BEV}$ life-cycle and the amount of emissions for lithium battery production can double in some cases [39]. According to this, there is no doubt that BEVs can help to reduce $\mathrm{CO}_{2}$ emissions, but the reduction is highly influenced by the source (type) of electricity production.

The current batteries' energy density limits their use to small or middle size passenger cars. The cost of batteries' production, relative low energy density and high weight, limit their wider use in commercial vehicles. According to Kalghatgi [18], the weight of a battery package for a heavy duty Class 8 truck would be more than four time higher than a typical diesel engine for this class of truck. The price of the battery pack alone will be higher than the entire truck with a diesel engine. The price of batteries and their weight, compared to conventional power trains/systems, even increases in air transport. The weight of the needed battery pack for the frequently used commercial Airbus A320 Neo would be 19 times higher than the maximum takeoff weight of the plane [18]. At current charging rates, that battery pack would need more than a week to become fully charged.

\subsection{Hybrid Vehicles}

Hybrid Vehicles (HVs) use the combination of an electrical engine and an Internal Combustion Engine to provide propulsion to the wheels of a vehicle. This combination can increase vehicle efficiency and decrease fuel consumption. The electricity to power an electric motor is stored in a battery pack, which is used as a second energy storage system. The combination of an IC Engine and an electric motor is managed in a way which optimises powertrain efficiency and decreases fuel consumption. The main benefit of hybrid vehicles is their capability to convert kinetic energy during braking into electricity, and to store it in a battery pack for upcoming usage. This energy is usually dissipated as heat into the atmosphere in vehicles with only IC engines. This also decreases the amount of pollution from brake wear.

Hybrid Vehicles can be found in two different configurations, Hybrid Electric Vehicles (HEVs) and Plug-in Hybrid Electric Vehicles (PHEVs). The main difference between them is that PHEVs can recharge their batteries during driving or using electricity from the grid, while conventional HEVs only charge their batteries during the driving process. This feature extends the driving range of PHEVs on pure electricity, and makes them far more usable than HEVs [40].

It was shown in previous studies that Hybrid Vehicles can decrease fuel consumption compared to conventional vehicles equipped with an IC Engine. The decrease of fuel consumption is more obvious in urban areas with several stop-start conditions. Hybrid Vehicles (HVs) can also help to decrease Nitrogen Oxide exhaust gas emissions. No major reduction in Hydro Carbon (HC) emissions was observed when using an HV. Carbon Oxide (CO) emission increased compared to conventional vehicles, because of frequent stop-start conditions, lower exhaust gas temperature and decreased efficiency of the catalytic converter [41]. 


\subsection{Fuel Cell Electric Vehicles}

The other possibility to power electric vehicles is the usage of Hydrogen or other type of electrolyte. Most of the fuel cells use Hydrogen to generate electricity in the vehicle. The produced electricity is then used to power the electric motors of the BEV, or it can power the assistant electric motors of hybrid vehicles. Compared to Battery Electric Vehicles, FCEV can be fuelled faster and allow a longer range. Different types of fuel cell can also use methanol, potassium hydroxide, liquid phosphoric acid, a molten carbonate salt mixture, and other specific materials, as a fuel for electricity production $[42,43]$.

Each type of fuel cell is designed to operate in a specific temperature range. Polymer Electrolyte Membrane (PEM) fuel cells, which are using Hydrogen as fuel, are the most appropriate for vehicle usage, since they operate at low temperatures. The main problem in massive (wider) use of PEM fuel cells is in the high costs of Hydrogen production and pure distribution system, as discussed earlier. This problem can be overcome with usage of Direct Methanol Fuel Cells (DMFCs), which are powered using pure Methanol. Methanol has higher energy density compared to Hydrogen and is easier to transport and supply but it toxic nature must be taken in to account when designing system for it usage $[42,43]$.

\subsection{Influence on the Energy sector}

The big question in wider usage of EVs is the increase in electricity consumption which will follow. Are we able to produce enough electricity to cover all our needs for daily transportation? Current final energy consumption in the $E U$ Transport sector is higher than the available electrical energy for final consumption, Figure 6.

The data presented in Figure 6 indicate that, at the moment, we do not produce enough electricity to cover all the energy needs in the Transport sector. As discussed earlier, the current weight and energy density of batteries limit the usage of electricity in light duty passenger cars used for personal mobility. Fuel consumption related to personal mobility accounted for $61 \%$ of the world's total transportation energy consumption in 2012, while light duty personal vehicles accounted for $44 \%$ of the world's total transportation energy consumption in 2012. This value depends on the specific country or region. In European OECD countries, the passenger vehicles account for approximately $50 \%$ of the region's total energy consumption in the Transport sector in 2012 [4]. Considering this data, we could, potentially, replace the fossil fuels used for combustion in light duty personal vehicles with electricity.

According to Eurostat [44], about $36.4 \%$ of electricity in the $E U$ is used by industry, more than $61.3 \%$ is used in households, and around $2.3 \%$ in the Transport sector. Using more electricity to power our vehicles can have a significant impact on the price of electricity for households, and for final products. If the price of electricity increases, it can also influence the competitiveness of our Industry sector.

If we look further, $48.7 \%$ of electricity generated in the $E U$ in 2016 came from burning combustible fuels like natural gas, coal or oil. More than a quarter, $25.7 \%$, of electricity was produced in nuclear power plants. The third biggest source of electricity generation are hydro power plants, with $12.1 \%$, followed by wind, $9.7 \%$ and solar with a $3.5 \%$ share [45].

There were a lot of discussions in recent years about de-fossilization of the Electricity Production sector in some European countries, especially in Germany. This can lead to a decrease in energy production (energy available for final consumption), which can have further influence on electricity prices for medium size households [46, 47].

\section{Energy requirements for fuels' production}

In recent years, a lot of discussion has been carried out about how much energy is required to produce liquid fuels (gasoline and diesel). Well-To-Tank (WTT) studies are suitable to determine the amount of energy needed to produce fuels which can be bought at petrol stations. Several studies were made to determine energy consumption during the refinery process in different regions (countries) [48-50]. The results for energy consumption in the $E U$ in the process for diesel and gasoline fuels' production are presented in Table 2.

The energy needed for fuel production can be seen from the presented results of energy balance, which show how much energy is required to produce a specific fuel. Around one fifth of final energy is used for fossil fuels' production. If we transform this, in electrical energy we can see that around $2 \mathrm{kWh}$ of electricity are needed to produce $1 \mathrm{~L}$ of diesel and gasoline fuels.

Most of the energy used in a refinery is produced from the raw material intake and is produced in the refinery. Some of the energy sources also need to be purchased [49]. Electricity used in the refining process is usually produced at the refinery power plant from fuels like furnace oil. Purchased electricity represents less than $5 \%$ of the energy consumed during the refinery process [48-50]. According to a JRC study [48], around a half of the energy used in WTT is used in the fuel refinery process. If we consider these data and assume that other stages of WTT also need to purchase the same amount of electricity (together $10 \%$ of the energy used in WTT), we get the different results of electrical energy used in fuel production, Table 2.

Based on the presented data, we can conclude that the amount of energy used in the refining process is not negligible. The energy used is produced from several sources, which are mostly by-products in the refinery, so they cannot be converted directly to electricity and used to power Electric Vehicles. By considering a 35\% efficiency of their transformation to electricity, it is possible to determine the amount of energy that, potentially, can be used to power EVs without considering any losses in electricity transportation (electrical grid losses), EV batteries, etc., Table 2.

The Well-To-Tank (WTT) studies enable us to evaluate the energy expanded and emissions emitted in the processes needed to produce specific fuels, and to deliver them to petrol stations. Tank To Wheels (TTW) studies further evaluate the energy expanded and emissions emitted by 


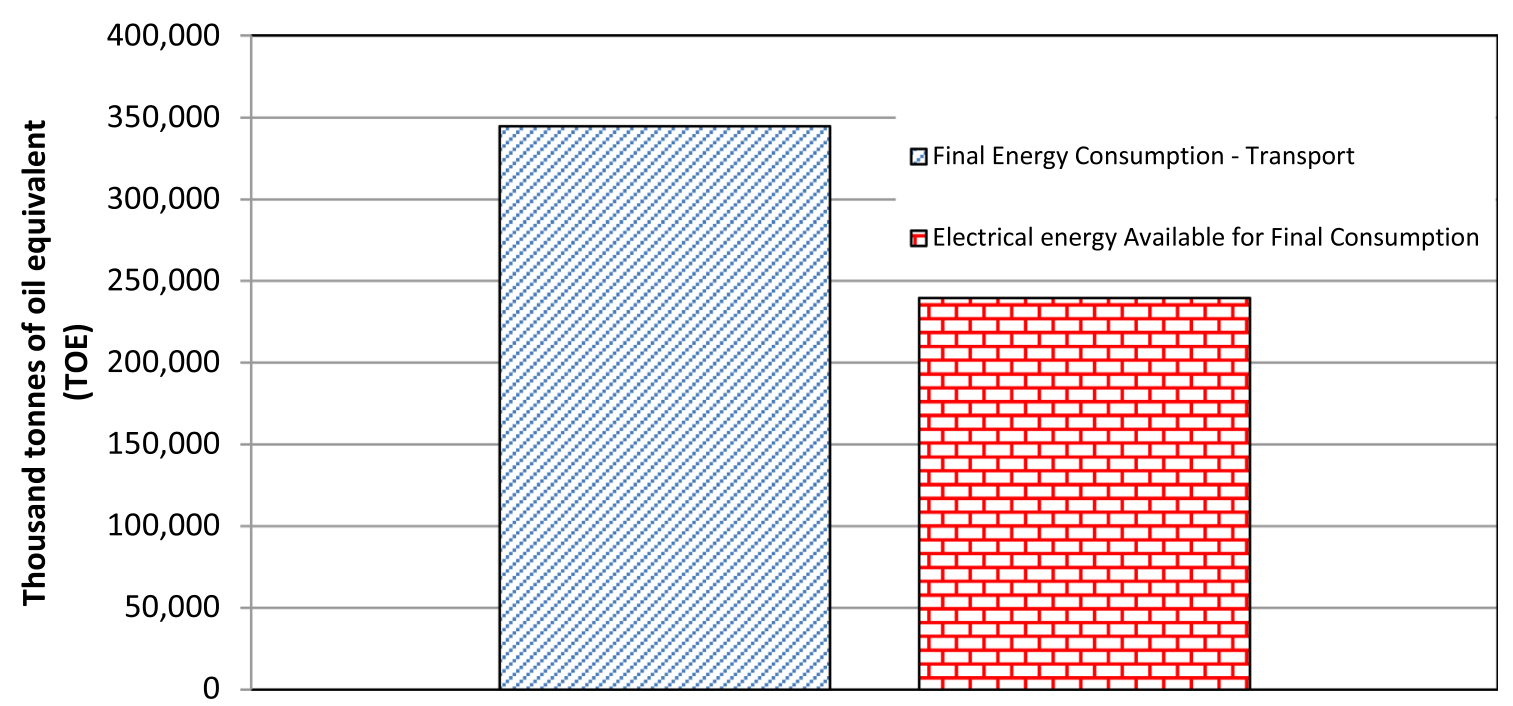

Fig. 6. The comparison of energy consumption in the Transport sector vs. electrical energy available for final consumption in the $\boldsymbol{E} \boldsymbol{U}$ in 2016 [44].

Table 2. Energy consumption during the refinery process in the $E U$.

\begin{tabular}{|c|c|c|c|}
\hline & Unit & Diesel & Gasoline \\
\hline Energy used in production & $\mathrm{MJ} / \mathrm{MJ}$ & 0.21 & 0.18 \\
\hline Density & $\mathrm{kg} / \mathrm{m}^{3}$ & 846.00 & 737.00 \\
\hline Calorific value & $\mathrm{MJ} / \mathrm{kg}$ & 45.60 & 46.40 \\
\hline Calorific value & $\mathrm{MJ} / \mathrm{L}$ & 38.58 & 34.20 \\
\hline \multicolumn{4}{|c|}{ Energy used in production of diesel and gasoline (in $\mathrm{kWh}$ equivalent) } \\
\hline Energy used & $\mathrm{kWh} / \mathrm{L}$ & 2.25 & 1.71 \\
\hline Energy used & $\mathrm{kWh} /$ gallon & 8.52 & 6.47 \\
\hline \multicolumn{4}{|c|}{ Electricity used in production (in $\mathrm{kWh}$ equivalent) } \\
\hline Energy used & $\mathrm{kWh} / \mathrm{L}$ & 0.233 & 0.17 \\
\hline Energy used & $\mathrm{kWh} /$ gallon & 0.853 & 0.65 \\
\hline \multicolumn{4}{|c|}{ Energy used in production considering $35 \%$ efficiency (in kWh equivalent) } \\
\hline Energy used & $\mathrm{kWh} / \mathrm{L}$ & 0.79 & 0.60 \\
\hline Energy used & $\mathrm{kWh} /$ gallon & 2.98 & 2.27 \\
\hline
\end{tabular}

specific vehicle and fuel combinations. If we sum those values, we get a Well-To-Wheels (WTW) study, which gives us an insight into the amount of energy expanded and emissions emitted by driving a vehicle with a specific engine type using different fuels or biofuels. The WTW study also considers different options for specific fuel production, like a different pathway for raw material distribution (NG from pipelines, NG from Shale gas, etc.), different raw materials for fuel production (biodiesel from Rapeseed oil, biodiesel from Sunflower oil, etc.), different types of used energy production ( $E U$ mix electricity, electricity from coal power plants, etc.) and similar.

In the presented paper, we summarise the results from the WTW study of the European Commission [48], for energy expended in $\mathrm{MJ} / 100 \mathrm{~km}$ and emissions emitted in g $\mathrm{CO}_{2 \mathrm{eq}} / \mathrm{km}$. In the case where several options for raw materials, pathways, etc., were available for a specific fuel type, we have calculated and used the average value. The study presents the WTW results for conventional 2010 year vehicles and for a 2020 option. The results for the 2020 option are containing advances in conventional technologies (reduction of vehicle aerodynamics drag, improvements in rolling resistance, weight reduction, engine downsizing and usage of after treatment systems) from the year 2010. In Figures 7 and 8, we present the WTW study results for energy expended and emissions emitted for the 2020 vehicle option (projection).

The usage of gasoline in Direct Injection Spark Ignition (DISI) and the usage of diesel fuels in Direct Injection Compression Ignition (DICI) engines are less energy consuming 

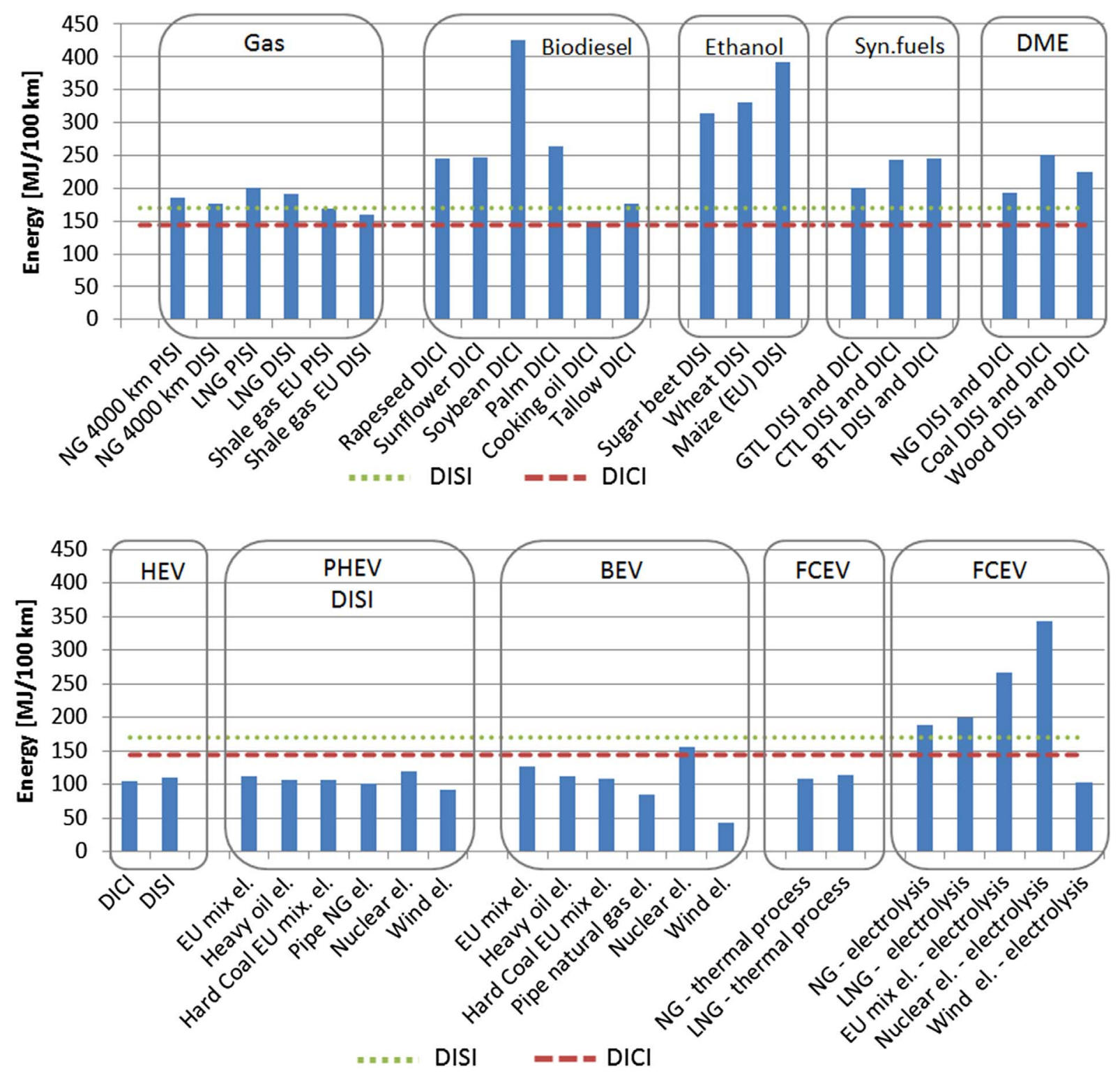

Fig. 7. Total energy expended in WTW for 2020 vehicle technology [48].

than usage of most of the alternative fuels considered, Figure 7. The energy increase is related to the higher energy intensity production of alternative fuels compared to conventional fuels' production. The energy intensity is also influenced by the combustion efficiency of each fuel and transport path of raw material (e.g., Natural Gas (NG) transported $4000 \mathrm{~km}$ in pipelines, or Shale gas pumped in the $E U)$. The Port Injection Spark Ignition (PISI) engines are slightly more energy consuming than Direct Injection Spark Ignition engines when running on Liquid Natural Gas (LNG).

When considering the results for ethanol and biodiesel we must bear in mind that the total energy is presented in Figure 7. The total energy consists of the chemical energy, stored in the biomass resource (raw material), and the energy needed for fuel production. The energy of the biomass source is several times higher than the fossil energy used. This is the reason why the Rapeseed, Sunflower, Soybean and Palm oil fuels are much more energy intense than Tallow and cooking oil fuels. The same influence as on the high energy intensity of all options of ethanol production.

All synthetic and DME fuels are also more energy consuming than conventional gasoline and diesel fuels. The energy consumption again depends on the raw material type used for fuel production. The production from coal (Coal To Liquid - CTL) and from biomass (Biomass To Liquid - BMT) consume more energy for synthetic fuel production than production from gas (Gas To Liquid - GTL). DME production is the same.

The situation is a bit different when comparing the results for energy consumption of $\mathrm{HEV}, \mathrm{PHEV}, \mathrm{BEV}$ and FCEV. Hybrid and Plug in Hybrid Electric Vehicles are less energy intensive than vehicles with conventional DISI and 

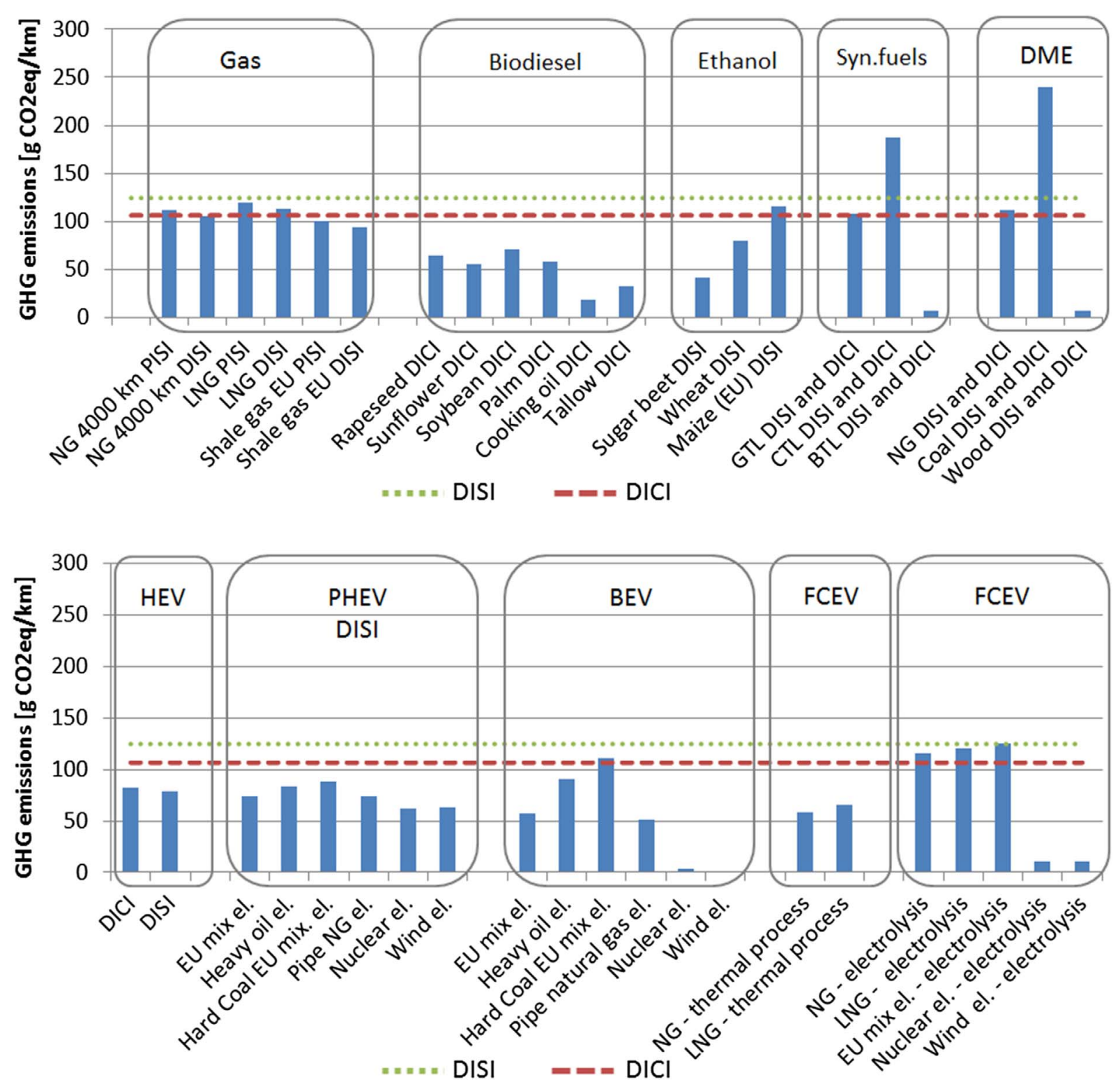

Fig. 8. Emissions emitted in WTW for 2020 vehicle technology [48].

DICI engines. The reason for less energy consumption is in their capability to convert kinetic energy during braking into electricity, and to store it in a battery pack for upcoming usage. This energy, which is normally wasted in vehicles with conventional engines, helps to decrease energy needs for powering hybrid vehicles.

In Battery and Plug in Hybrid Electric Vehicles, energy consumption depends strongly on the type of electricity source. The lower efficiency in electricity production is achieved in nuclear power plants, so the energy consumption of BEVs and PHEVs is the highest when nuclear power plants are used for electricity production.

The usage of Hydrogen in a Fuel Cell Electric Vehicle depends strongly on the method of producing Hydrogen. The thermal process of Hydrogen production from both Natural Gas (NG) and Liquid Natural Gas (LNG) is less energy consuming than fossil fuel usage. The electrolysis pathways of Hydrogen production are more energy intensive. The exception is only the path where electricity produced from wind is used.

All combinations of vehicles and fuels emit certain amounts of emissions. The amount of emitted emissions in the WTW study is presented in Figure 8.

The trends for emitted emissions when using different alternative fuels are different than the trends for energy consumption. The usage of compressed Natural Gas emits more or less the same amount of emissions as usage of gasoline and diesel fuels, while all other considered biofuels emitted far less emissions. The amount of energy needed to produce biofuels, depends strongly on the raw material used. This results in different amounts of emitted emissions for different raw material biofuels' pathways. The emissions 
emitted in the ethanol and synthetic fuels' pathway also depends strongly on the raw material used. Different raw materials need different approaches for fuel production, which results in different emissions' intensities for each type of raw material. When considering the results for emission intensity of DME, the production of DME from wood is the most favourable. The main energy source in wood transformation to DME is the wood itself, so the amount of emitted emissions is very low compared to DME production from Natural Gas or coal.

When comparing the results from Hybrid Vehicles to vehicles with conventional engines, the lower energy intensity, seen from the results in Figure 8, influences the lower amount of emitted GHG emission. The amount of emitted GHG emissions in a Battery Electric Vehicle depends only on the type of electricity production process. The coal and heavy oil electricity production processes are by far the most emission intense. The electricity produced from wind and in nuclear power plants is the most clean. This is also reflected in FCEVs, where the electrolysis process is used for Hydrogen production.

\section{Conclusion}

The presented paper studies the current situation in the field of Road Application Propulsion Systems' development. In recent years, Hybrid and Electric Vehicles have made a lot of progress in their development and usability. Despite all the progress made, the current road transport system is still based on Internal Combustion Engines and liquid, petroleum based fuels' combustion. The market share of all BEV and all Hybrid Vehicles in European countries in 2016 was around $3.4 \%$.

The global demand for petroleum based fuels is growing yearly [18]. The total wind and solar energy produced in 2016 was able to cover 12 days of global energy demand in the Transport sector. This shows us the everyday dimension of energy demands in the Transport sector, and indicates the complexity of replacing its current primary energy source. Current trends in electricity production and battery capacity are not in favour of wider electricity usage in the Transportation sector. There is also a question concerning the electricity network capacity to transport more electricity in the case that more and more households will possess Electric Vehicles which need to be charged regularly.

On the other hand, recent progress in the development of Internal Combustion Engines improves their efficiency and lowers exhausts gas emissions. Modern combustion technologies and new exhaust gas after treatment technologies decrease the amount of harmful emissions significantly, especially from diesel engines. Exhaust gas emissions are heavily regulated by the EURO and other national norms, which foster the development of new techniques for additional emissions' reduction. They also encourage the usage of biofuels, which are being mixed with petroleum based fuels in most $E U$ countries, and have a proven positive impact on emission reduction. The usage of biofuels combined with modern combustion technologies or with hybrid propulsion systems, can have an even bigger impact on emission reduction than each individual solution.

When considering other alternatives to conventional fuels, like synthetic fuels, DME and Hydrogen, we must be very careful. As seen from the WTW study, some of them may have a greater emission impact on the environment compared to diesel and gasoline fuels. The electricity production in some European countries is still very coal dependent. This type of electricity production is also very emission intensive, and can be more harmful to the environment than usage of conventional, petroleum based liquid fuels in the Transport sector.

Electricity will certainly play an important role in the future of road propulsion systems. How big its contribution will be depends on the future development of battery capacity, upgrades in electricity network capacity, decarbonization of the Electricity Production sector, future trends in automotive development, etc. A big concern is also the price of electricity, and the decrease of collected road taxes from fossil fuels' sale, which is expected to follow at a certain point of the transition towards transport electrification. As seen in recent market shares, the Hybrid Electric Vehicles, in all forms, have the biggest potential for mass use in the future.

All this indicates that, in the near future, Internal Combustion Engines will still have the major role in all types of road applications. The combination of modern ICE with increased efficiency and lower emission impact with partial vehicle electrification currently presents the best solution to decrease greenhouse gas emissions in the near future. The available technologies need to be balanced according to the specific characteristics of each region. Considering this, further investments in new IC engines' technologies, exhaust gas after treatment systems and biofuels, are necessary for further reduction of the environmental impact of the Transport sector in the near future.

\section{References}

1 BP Statistical Review of World Energy. (2018) https://www. bp.com/content/dam/bp/business-sites/en/global/corporate/ pdfs/energy-economics/statistical-review/bp-stats-review-2018full-report.pdf [accessed 12 Mar 2019].

2 IEA. (2018) Global Energy \& $\mathrm{CO}_{2}$ Status Report 2017, International Energy Agency.

3 BP Energy outlook. (2017) https://www.bp.com/content/ $\mathrm{dam} / \mathrm{bp} / \mathrm{pdf} /$ energyeconomics/energy-outlook-2017/bpenergy-outlook-2017.pdf [accessed 26 Feb 2018].

4 International Energy Outlook. (2016) Energy Information Administration, 2016.

5 EEA. (2018) Progress of EU transport sector towards its environment and climate objectives, European Environment Agency.

6 Eurostat. (2018) Energy, transport and environment indicators, 2018 edition, European Union, Luxenburg. ISBN 97892-79-96509-8 ISSN 2363-2372.

7 EEA. (2018) Fuel quality in the EU in 2016, European Environment Agency, doi: 10.2800/224432. 
8 European Vehicle Market Statistics. (2017) The International Council on Clean Transportation, http://eupocketbook. theicct.org.

9 EEA. (2018) Emissions of air pollutants from transport, European Environment Agency.

10 Williams M., Minjares R. (2016) A technical summary of Euro 6/VI vehicle emission standards, icct, Accessible online on https://www.theicct.org [accessed 3.04.2019].

11 EEA. (2018) European Union emissions inventory report 1990-2016 under the UNECE Convention on Long-range Transboundary Air Pollution (LRTAP), European Environment Agency, ISSN 1977-8449.

12 EEA. (2018) Final energy consumption by mode of transport, European Environment Agency.

13 Eurostat, http://appsso.eurostat.ec.europa.eu/nui/submit ViewTableAction.do [accessed 26 Mar 2019] Key words: Passenger cars per 1000 inhabitants.

14 Heywood J., MacKenzie D. (2015) On the road toward 2050: Potential for substantial reductions in light-duty vehicle energy use and Greenhouse Gas Emissions, Massachusetts Institute of Technology Sloan Automotive Laboratory, Engineering System Division.

15 Mao B., Peng C., Haifeng L., Zunqing Z., Mingfa Y. (2018) Gasoline compression ignition on a multi-cylinder heavy duty diesel engine, Fuel 2015, 339-351.

16 An Y., Jaasim M., Raman V., Hernández Pérez F.E., Sim J., Chang J., Im H.G., Johansson B. (2018) Homogeneous charge compression ignition (HCCI) and partially premixed combustion (PPC) in compression ignition engine with low octane gasoline, Energy 158, 181-191.

17 Kalghatgi G., Johansson B. (2018) Gasoline Compression Ignition (GCI) approach to efficient, clean, affordable future engine, Proc. Inst. Mech. Eng. Part D: J. Automob. Eng. 232, 1, 118-138.

18 Kalghatgi G. (2018) Is it really and of internal combustion engines and petroleum in transport? Appl. Energy 225, 965-974.

19 Wang L., Lowrie J., Ngaile G., Fang T. (2019) High injection pressure diesel sprays from a piezoelectric fuel injector, Appl. Therm. Eng. 15, 807-824.

20 Morgan R., Banks A., Auld A., Heikal M. (2015) The benefits of high injection pressure on future heavy duty engine performance, SAE Technical Paper 2015-24-2441, doi: $10.4271 / 2015-24-2441$.

21 Stanton D. (2013) Systematic development of highly efficient and clean engines to meetfuture commercial vehicle greenhouse gas regulations, SAE Int. J. Eng. 6, 3, 1395-1480. doi: 10.4271/2013-01-2421.

22 Huang W., Moon S., Gao Y., Wang J., Ozawa D., Matsumoto A. (2019) Hole number effect on spray dynamics of multi-hole diesel nozzles: An observation from three- to nine-hole nozzles, Exp. Therm. Fluid Sci. 102, 387-396.

23 Karthickeyan V. (2019) Effect of combustion chamber bowl geometry modification on engine performance, combustion and emission characteristics of biodiesel fuelled diesel engine with its energy and exergy analysis, Energy 176, 830-852.

24 Pappula B., Pitchaipillai P., Narayanan K.G. (2019) Combined effect of composite additive and combustion chamber modification to adapt waste plastic oil as fuel on a diesel engine, J. Taiwan Inst. Chem. Eng. 97, 297-304.

25 Han D., Duan Y., Wang C., Lin H., Huang Z. (2015) Experimental study on the two stage injection of diesel and gasoline blends on a common rail injection system, Fuel 159, 470-475.
26 Payri F., Luján J.M., Guardiola C., Pla B. (2014) A challenging future for the IC engine: New technologies and the control role, Oil Gas Sci. Technol. - Rev. IFP Energies nouvelles 70, 15-30. doi: 10.2516/ogst/2014002.

27 Ayodhya A., Narayanappa K. (2018) An overview of aftertreatment systems for diesel engines, Environ. Sci. Pollut. Res. 25, 1-4. doi: 10.1007/s11356-018-3487-8.

28 Exxonmobil, Outlook for energy: A view to 2040, https://cdn. exxonmobil.com/ /media/global/files/outlook-for-energy/ 2017/2017-outlook-for-energy.pdf [accessed 31.1.2019].

29 US DOE. Alternative Fuels Data Center. (2019) Hydrogen production and distribution, https://afdc.energy.gov/fuels/ hydrogen_production.html [accessed 31.1.2019].

30 US DOE. (2009) Energy requirement for hydrogen gas compression and liquefaction as related to vehicle sorage needs, https://www.hydrogen.energy.gov/pdfs/9013_energy_ requirements_for_hydrogen_gas_compression.pdf [accessed 31.1.209].

31 You-Kwan O., Kyung-Ran H., Changman K., Jung R.K., Jin-Suk L. (2018) Recent developments and key barriers to advanced biofuels: A short review, Bioresource Technol. 257, 320-333.

32 Ahlgren E., Hagberg M.B., Grahn M. (2017) Transport biofuels in global energy-economy modelling - a review of comprehensive energy systems assessment approaches, $G C B$ Bioener. 9, 1168-1180.

33 Alalwan H.A., Alminshid A.H., Aljaafari H.A.S. (2019) Promising evolution of biofuel generation. Subject review, Renew. Energy Focus 28, 127-139.

34 Sikarwar V.S., Zhao M., Fennell P.S., Shah N., Anthony E.J. (2017) Progress in biofuel production from gasification, Process Ener. Combust. Sci. 61, 189-248.

35 World Bank, GGFR partners unlock value of wasted gas, http://web.worldbank.org/WBSITE/EXTERNAL/TOPICS/ EXTSDNET/0,,contentMDK:22416844 menuPK:64885113 pagePK:64885161 piPK:64884432 theSitePK:5929282,00. html [accessed 29.1.209].

36 Mom G. (2014) The Evolution of Automotive Technology: A handbook, SAE International.

37 Safari M. (2018) Battery electric vehicles: Looking behind to move forward, Energy Policy 115, 54-65.

38 Hall D., Lutsey N. (2018) Effects of battery manufacturing on electric vehicle life-cycle greenhouse gas emissions, icct. Accessible online on www.theicct.org [accessed 15.04.2019].

39 Deetman S., Pauliuk S., van Vuuren D.P., van der Voet E., Tukker A. (2018) Scenarios for demand growth of metal in electricity generation technologies, cars, and electronic appliances, Environ. Sci. Technol. 52, 4950-4959.

40 Sabri M.F.M., Danapalasingam K.A., Rahmat M.F. (2016) A review on hybrid electric vehicles architecture and energy management strategies, Renew. Sust. Energ. Rev. 53, 1433-1442.

41 Huang Y., Suarawski N.C., Organ B., Zhou J.L., Tang O.H.H., Chan E.F.C. (2019) Fuel consumption and emissions performance under real driving: Comparison between hybrid and conventional vehicles, Sci. Total Environ. 659, 275-282.

42 Office of Energy Efficiency and Renewable Energy. (2019) Types of Fuel Cells, https://www.energy.gov/eere/fuelcells/ types-fuel-cells [accessed 16.04.2019].

43 Tanc B., Arat H.T., Baltacioglu E., Aydin K. (2019) Overview of the next quarter century vision of hydrogen fuel cell electric vehicles, Inter. J. Hydrogen Ener. 44, 1012010128. 
44 Eurostat internetna stran. (2018) iskalne besede: supply, transformation and consumption of electricity and oil, 5.10.2018.

45 Eurostat. (2018) Electricity production, consumption and market overview. Statistic explained, Eurostat.

46 Renn O., Marshall J.P. (2016) Coal, nuclear and renewable energy policies in Germany: From the 1950s to the "Energiewende", Energy Policy 99, 224-232.

47 Hake J.F., Fischer W., Venghaus S., Weckenbrock C. (2015) The German Energiewende - History and status quo, Energy 92, 532-546. doi: 10.1016/j.energy.2015.04.027.

48 JRC. (July, 2013) Well to Wheels analysis of future automotive fuels and powertrains in the European context, Version 4, European Commission, Joint Research Centre, Institute of Energy and Transport.

49 Imran Khan M. (2018) Comparative Well-to-Tank energy use and greenhouse gas assessment of natural gas as a transportation fuel in Pakistan, Ener. Sustain. Develop. 43, $38-59$.

50 Patil V., Shastry V., Himabindu M., Ravikrishna R.V. (2016) Life-cycle analysis of energy and greenhouse gas emissions of automotive fuels in India: Part 2 - Well-to-wheels analysis, Energy 96, 699-712.

51 European Union. (2016) Energy balance sheets 2016 DATA, European Union, Luxembourg. ISBN 978-92-79-92826-0 ISSN 1830-7558.

52 Eurostat, http://appsso.eurostat.ec.europa.eu/nui/submit ViewTableAction.do [accessed 18.03.2019].

53 Eurostat, https://ec.europa.eu/eurostat/web/products-datasets/-/ road_eqr_carpda [2.10.2018].

54 Eurostat, http://appsso.eurostat.ec.europa.eu/nui/show.do? dataset $=$ env_air_emis\&lang $=\mathrm{en}$ [accessed 28 Mar 2019]. 